\title{
K-Ca ages of authigenic sediments: examples from Paleozoic glauconite and applications to low-temperature thermochronometry
}

\author{
M. Robinson Cecil • Mihai N. Ducea
}

Received: 2 June 2009/Accepted: 30 October 2010/Published online: 4 December 2010

(C) The Author(s) 2010. This article is published with open access at Springerlink.com

\begin{abstract}
K}-\mathrm{Ca}$ ages of Cambrian glauconites from the Llano uplift, central Texas, were determined in order to reevaluate the ability of the $\mathrm{K}-\mathrm{Ca}$ system to constrain the timing of deposition of sedimentary packages. All of the $\mathrm{K}-\mathrm{Ca}$ ages presented here were found to be younger than their stratigraphic ages. In addition to being too young, the $\mathrm{K}-\mathrm{Ca}$ ages are also highly variable, ranging in age from Silurian to Permian. The oldest subset of glauconite ages are in agreement with previously published $\mathrm{Rb}-\mathrm{Sr}$ ages from the same outcrop and provide further evidence for there having been a post-depositional thermal or recrystallization event that reset both the $\mathrm{Rb}-\mathrm{Sr}$ and $\mathrm{K}-\mathrm{Ca}$ systems. The range of younger glauconite $\mathrm{K}-\mathrm{Ca}$ ages is similar to the distribution of available apatite fission track ages for the Llano basement. $\mathrm{K}-\mathrm{Ca}$ ages are interpreted as thermochronologic data reflecting partial retention of $\mathrm{Ca}$ in thermally fluctuating basin conditions. Estimates of the closure temperature of $\mathrm{Ca}$ in glauconite are found to be $60-90^{\circ} \mathrm{C}$ for cooling rates of $\sim 0.5-1{ }^{\circ} \mathrm{C} / \mathrm{My}$. The $\mathrm{K}-\mathrm{Ca}$ system is potentially useful as a low-temperature thermochronometer with closure temperatures $<100^{\circ} \mathrm{C}$ for glauconite.
\end{abstract}

Keywords K-Ca isotopes - Thermochronology · Sedimentary rocks

M. R. Cecil · M. N. Ducea $(\bowtie)$

Department of Geosciences, University of Arizona,

Tucson, AZ 85721, USA

e-mail: ducea@email.arizona.edu

\section{Introduction}

Reliable dating of sedimentary rocks is important to the calibration of the geologic time scale and to the timing and cyclicity of depositional events. Determining the ages of sedimentary units is difficult, however, unless they contain useful biostratigraphic markers or interbedded volcanics (e.g. Odin 1982). It is also made difficult by the fact that sedimentation can occur over relatively lengthy amounts of geologic time. For that reason, direct dating of deposition/ sedimentation is not always possible, but can be closely constrained through radiometric dating of authigenic and diagenetic sedimentary minerals. Depending upon the minerals targeted, however, the diagenetic age can be highly variable and considerably younger than the depositional age (e.g. Brookins et al. 1980; Obradovich 1988). It is not clear how much of that variability is a result of depositional processes and how much is a function resetting during the subsequent thermal history of the sedimentary basin (Evernden et al. 1961).

Both the $\mathrm{Rb}-\mathrm{Sr}$ and the (K)Ar-Ar systems have been shown to commonly yield erroneously young ages, most likely due to the loss of radiogenic daughter products through diffusion or ion exchange processes (e.g. Hurley et al. 1960, 1961; Thompson and Hower 1973; Morton and Long 1980; Brookins et al. 1980). Given the stable, nonvolatile nature of calcium, the relatively short half-life of ${ }^{40} \mathrm{~K}$, and the fact that potassium and calcium are both major constituents in rock-forming minerals, the $\mathrm{K}-\mathrm{Ca}$ system has great potential for geochronometric applications (Marhsall and DePaolo 1982). Comparative studies examining the $\mathrm{K}-\mathrm{Ca}$ system have suggested that $\mathrm{Ca}$ is a more immobile and retentive daughter and $\mathrm{K}-\mathrm{Ca}$ ages are more resistant to resetting (Marshall et al. 1986; Shih et al. 1994; Nagler and Villa 2000). K-Ar ages of authigenic feldspar 
(Marshall et al. 1986) and Ar-Ar ages of pegmatitic micas (Nagler and Villa 2000) are consistently younger than the corresponding $\mathrm{K}-\mathrm{Ca}$ ages, due to diffusive loss of ${ }^{40} \mathrm{Ar}$, even at low temperatures. Likewise, $\mathrm{Rb}-\mathrm{Sr}$ mineral isochron ages of lunar granites are younger than $\mathrm{K}-\mathrm{Ca}$ isochron ages of the same granites (Shih et al. 1994). Although there are studies indicating that $\mathrm{K}-\mathrm{Ca}$ geochronology is particularly useful for sedimentary dating (e.g. Polevaya et al. 1958; Marshall et al. 1986; Baadsgaard 1987; Gopalan 2008), published K-Ca sedimentary dates are relatively few. Because ${ }^{40} \mathrm{Ca}$ is the most abundant stable isotope of calcium, enrichments in radiogenic ${ }^{40} \mathrm{Ca}$ are relatively small and only measurable in materials that are old (Paleozoic_-Precambrian) and/or have high $\mathrm{K} / \mathrm{Ca}$ values. A new analytical method for measuring radiogenic $\mathrm{Ca}$ ratios using multi-collector ICP-MS has contributed to improvements in rapid and precise $\mathrm{Ca}$ isotopic analysis (Cecil 2009).

Here, we present new $\mathrm{K}-\mathrm{Ca}$ ages from authigenic Cambrian glauconites from the Llano Uplift as a means for evaluating the utility and robustness of the $\mathrm{K}-\mathrm{Ca}$ system in dating sedimentary minerals. The principal findings are that the $\mathrm{K}-\mathrm{Ca}$ ages are younger than the sedimentary deposition of dated units, but they may record heating during diagenesis and cooling below closure temperatures less than $100^{\circ} \mathrm{C}$, thus making the $\mathrm{K}-\mathrm{Ca}$ system a potentially useful low-temperature thermochronometer.

\section{Approaches to sedimentary geochronology}

Sedimentary minerals having chemistries appropriate for geochronometric dating are commonly targeted to constrain depositional timing. Recent innovations in this field include $\mathrm{U}-\mathrm{Pb}$ dating of diagenetic xenotime (McNaughton et al. 1999), monazite (Evans et al. 2002) and organic-rich calcite (Becker et al. 2002). More classical approaches have focused on sedimentary minerals rich in $\mathrm{K}$ (and $\mathrm{Rb}$ ) and are therefore suitable for dating using $\mathrm{K}-\mathrm{Ar}$, $\mathrm{Ar}-\mathrm{Ar}$ and $\mathrm{Rb}-\mathrm{Sr}$ techniques. Such minerals have included authigenic K-spar (Marshall et al. 1986), illite (Clauer et al. 1997; Srodon et al. 2002) and K-rich evaporites such as sylvite, carnallite, langbeinite or polyhalite (e.g. Baadsgaard 1987; Brookins et al. 1980; Renne et al. 2001). Most of these techniques have proven problematic and have achieved only moderate success. In the case of illite, it can be difficult to distinguish detrital from authigenic populations and in the case of evaporite samples, dating is difficult given the readiness of radiogenic ${ }^{40} \mathrm{Ar}$ to diffuse out of certain K-salt species (Brookins et al. 1980).

Perhaps the most commonly used mineral for dating of siliciclastic sediments is glauconite, a K-rich phyllosilicate that forms from clay precursors in a marine environment (Rongbing 1989; Clauer et al. 1992; Stille and Clauer
1994; Meunier and El Albani 2007). In fact, almost half of the absolute ages used in constructing the Mesozoic and Cenozoic time scale are derived from Ar-Ar ages of glaucony series minerals (Smith et al. 1998). Glauconites are particularly attractive targets because they are common in sediments of all ages from the Precambrian throughout the Phanerozoic, are easily recognized in the field, and can be determined to be authigenic on the basis of their chemical, textural and X-ray characteristics (Odin 1982). Glauconite age data, however, are often viewed with skepticism (e.g. Obradovich 1988), as ages are frequently discrepant between systems and are overall too young (Hurley et al. 1960; Hurley 1961; Thompson and Hower 1973; Morton and Long 1980) and sometimes too old (Owens and Sohl 1973; Montag and Seidemann 1981). Leaching experiments for $\mathrm{Rb}-\mathrm{Sr}$ analysis (Morton and Long 1980) and single grain $\mathrm{Ar}-\mathrm{Ar}$ laser probe analysis (Smith et al. 1998) have not significantly improved the reliability of glauconite ages.

Several early pioneering studies were conducted, in which K-Ca ages of lepidolites (Ahrens 1951), glauconite (Herzog 1956), and sylvite (Polevaya et al. 1958) were determined. $\mathrm{K}-\mathrm{Ca}$ geochronology is seldom used, however, due to difficulties measuring $\mathrm{Ca}$ isotopes with conventional TIMS methods, and the general difficulty of measuring sedimentary deposits, which form slowly and are prone to alteration and non-closed system behavior. A handful of more recent studies using $\mathrm{K}-\mathrm{Ca}$ to date $\mathrm{K}$-rich evaporites (Baadsgaard 1987) and glauconites (Gopalan 2008) have emerged, but $\mathrm{K}-\mathrm{Ca}$ sedimentary geochronological data are relatively few.

\section{Sample preparation and analytical methods}

Isotopic and geochronologic data from seven glauconite samples and six K-rich evaporite samples are presented here. Glauconitic sandstone samples were hand crushed, sieved and divided into the following size fractions: 63-105, 105-150, 150-247, and 247-420 $\mu \mathrm{m}$, which correspond to samples named GL 105, GL 150, GL 247, and GL 420, respectively. Glauconites were separated from the size fractions via magnetic separation using standard techniques described in Clauer et al. (2005). Two glauconite aliquots from each size group were powdered and approximately $15-25 \mathrm{mg}$ of sample powder were weighed and transferred to $15 \mathrm{~mL}$ screw top Teflon vials. We performed leaching experiments on one set of aliquots by first rinsing the samples with acetone and water and then putting them in $1 \mathrm{~mL}$ of $1 \mathrm{M} \mathrm{HCl}$. Samples were leached for $\sim 15 \mathrm{~min}$, including $5 \mathrm{~min}$ of ultrasonication, and then centrifuged. The leachates were saved for analysis, and the residues, along with non-leached samples, were dissolved 
following the silicate dissolution procedure outlined in Cecil (2009).

Once fully dissolved, all samples were spiked with ${ }^{44} \mathrm{Ca}$ and ${ }^{41} \mathrm{~K}$ tracers and allowed to homogenize for $24 \mathrm{~h}$ on a hot plate at $120^{\circ} \mathrm{C}$. $\mathrm{K}$ and $\mathrm{Ca}$ were separated using $1-\mathrm{cm}-$ diameter quartz columns filled with Dowex AG50 W-X8 resin (200-400 mesh) to a height of $17 \mathrm{~cm}$. Elemental separates were evaporated to dryness and later redissolved and diluted in $2 \% \mathrm{HNO}_{3}$.

Isotopic measurements were performed on a GV IsoProbe MC-ICP-MS, using gas-phase reactions in a hexapole collision cell to minimize isobaric Ar interference (Cecil 2009). All samples were introduced in $2 \% \mathrm{HNO}_{3}$ through an Aridus desolvating nebulizer. Sample ${ }^{40} \mathrm{Ca} /{ }^{42} \mathrm{Ca}$ ratio measurements were corrected using a sample-bracketing technique, made possible by the good reproducibility $\left(0.02 \%\right.$ RSD) of the standard ratios. ${ }^{39} \mathrm{~K} /{ }^{41} \mathrm{~K}$ ratios were also normalized to the standard ratio (Cecil 2009).

\section{K-Ca dating of Cambrian glauconite}

Glauconite samples were collected from the Upper Cambrian Lion Mountain sandstone (Riley Fm) in the Llano uplift, central Texas. The Llano uplift is a Proterozoic basement high, which exposes polydeformed metamorphic and granitic rocks associated with a Grenvillian orogenic belt bordering the southern margin of Laurentia (Mosher 1998). It is rimmed by Cambrian-Pennsylvanian terrigenous and shallow marine sedimentary units that dip gently away from the basement uplift, forming a broad anticlinorium with the older (basement) rocks in the core. Apatite fission track age distribution in the basement rocks forming the core of the Llano uplift have Paleozoic ages, showing that the core of the Llano uplift was also buried during the deposition and diagenesis of the Paleozoic section (Corrigan et al. 1998) and that the burial depth was around $2 \mathrm{~km}$. The Paleozoic section is in turn flanked by a thin on-lapping section of Cretaceous carbonates (Fig. 1). The 15-m-thick Lion Mountain sandstone is a dark green, medium-grained unit, composed primarily of glauconite pellets and larger carbonaceous nodules (McBride 1988) that lies conformably above the lower Riley Formation Hickory sandstone and Cap Mountain limestone members (see Morton and Long 1980, for a more detailed description of the stratigraphy).

Glauconite samples were separated into four size fractions and divided into two sets of aliquots for leaching experiments. The size separation was performed in order to test whether or not more mature or pure glauconite existed in a specific size range and to determine whether the abundance of radiogenic $\mathrm{Ca}$ and/or age was dependent on the size of the glauconite grains analyzed. Leaching was performed in order to remove loosely bound $\mathrm{Ca}$ and to determine the effect of common $\mathrm{Ca}$ on the $\mathrm{K}-\mathrm{Ca}$ age. Seven K-Ca ages range broadly from 223 to $434 \mathrm{Ma}$ (Table 1). There is no apparent correlation neither between age and grain size, nor between age and leached/unleached sample aliquots. It should be noted, however, that the three Permian-aged samples reported here were not leached. Leachates extracted during chemical sample preparation were analyzed and ${ }^{40} \mathrm{Ca} /{ }^{42} \mathrm{Ca}$ ratios were found to be indistinguishable from standard ${ }^{40} \mathrm{Ca} /{ }^{42} \mathrm{Ca}$ values, indicating that all of the $\mathrm{Ca}$ removed during leaching was likely common, loosely bound $\mathrm{Ca}$ from associated carbonate.

\section{Comparison of $\mathrm{K}-\mathrm{Ca}, \mathrm{Rb}-\mathrm{Sr}$, and AFT ages}

The oldest $\mathrm{K}-\mathrm{Ca}$ ages (434 and $429 \mathrm{Ma}$ ) are identical within error with $\mathrm{Rb}-\mathrm{Sr}$ ages from glauconites sampled at the same outcrop, as determined by Morton and Long (1980) (Fig. 2a). These Silurian ages are younger than the assumed depositional age of $515 \mathrm{Ma}$ by approximately $16 \%$. Morton and Long (1980) interpret the 430 m.y. age to represent the timing of maximum burial and recrystallization that occurred during deposition of at least $700 \mathrm{~m}$ of strata from the late Cambrian to the early Ordovician and before an inferred period of unroofing between the middle Ordovician and the early Devonian. Because all $\mathrm{Rb}-\mathrm{Sr}$ ages cluster between 410 and $430 \mathrm{Ma}$, recrystallization is thought to chemically stabilize the glauconite, making it impervious to alteration and resetting of the $\mathrm{Rb}-\mathrm{Sr}$ system. The fact that the oldest $\mathrm{K}-\mathrm{Ca}$ ages are coincident with the $\mathrm{Rb}-\mathrm{Sr}$ ages provides further evidence for there having been a Silurian diagenetic/recrystallization event. Unlike the clustered $\mathrm{Rb}-\mathrm{Sr}$ ages, however, the $\mathrm{K}-\mathrm{Ca}$ ages presented here are highly variable and are as young as $223 \mathrm{Ma}$.

Although the widely distributed $\mathrm{K}-\mathrm{Ca}$ ages are not similar to $\mathrm{Rb}-\mathrm{Sr}$ ages, the range of $\mathrm{K}-\mathrm{Ca}$ ages (434$223 \mathrm{Ma}$ ) is the same as the range of apatite fission track ages from the Llano basement (425-240 Ma) (Corrigan et al. (1998). Age information from the Precambrian basement and the overlying strata are not directly comparable; however, their close stratigraphic relationship (less than $200 \mathrm{~m}$ ) implies a shared post-Cambrian burial history. Modeling of the wide range of Paleozoic apatite fission track ages and the negatively skewed nature of the track length distributions suggest a protracted burial history, with maximum burial (depths between 2 and $2.5 \mathrm{~km}$, assuming a geothermal gradient of $25^{\circ} \mathrm{C} / \mathrm{km}$ ) occurring in the Permian (after Corrigan et al. 1998).

The distribution of the $\mathrm{K}-\mathrm{Ca}$ ages corresponds to a period of time in which the Llano basement and overlying Cambrian units were at depths of 1-2 km and burial-related heating resulted in temperatures of at least $50-60^{\circ} \mathrm{C}$, based on the integrated thermal history of the Llano uplift 


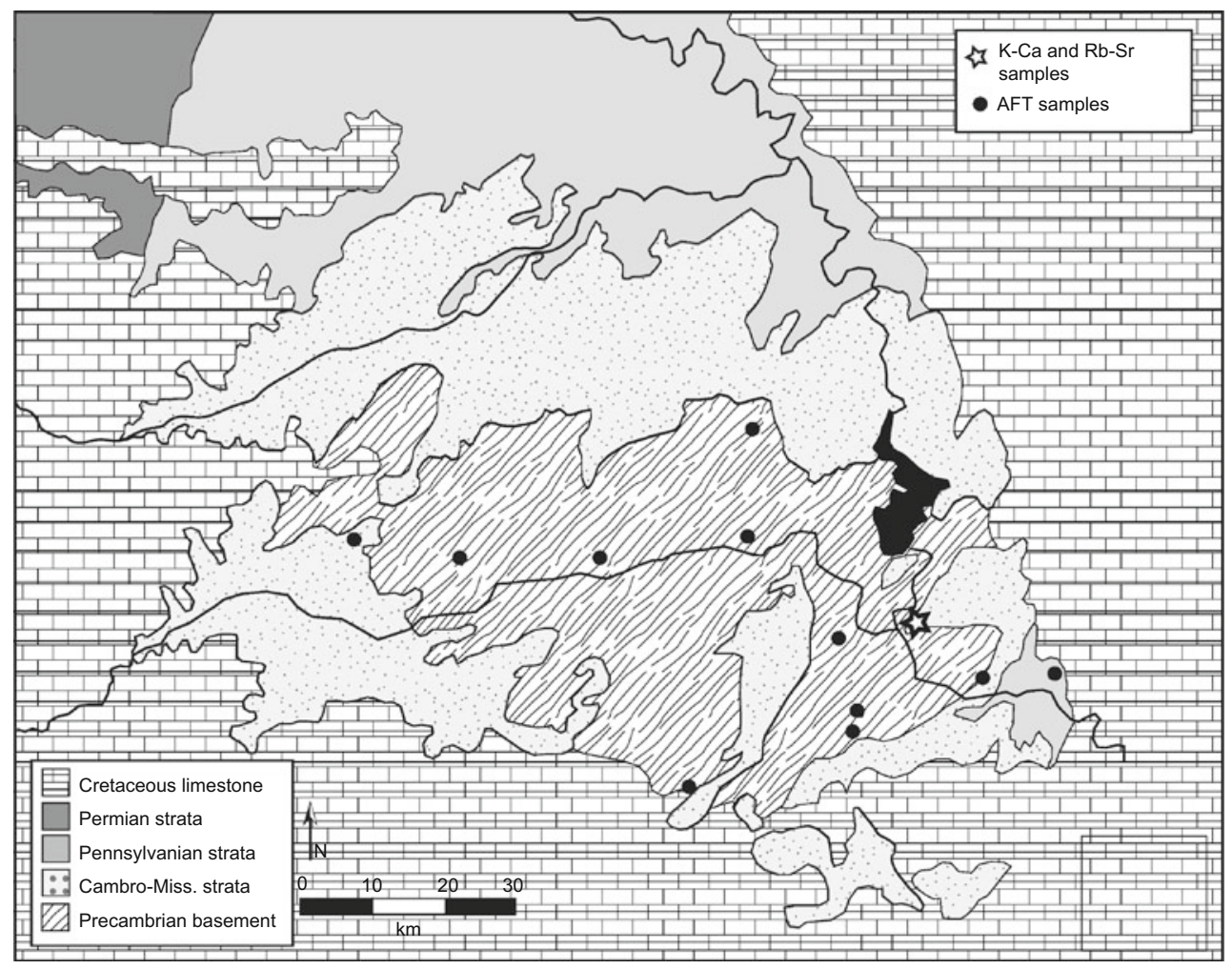

Fig. 1 Generalized geologic map of the Llano uplift, Central Texas, showing the relationship between the Precambrian basement high and the surrounding Paleozoic and Cretaceous strata. K-Ca (this study) and $\mathrm{Rb}-\mathrm{Sr}$ (Morton and Long 1980) ages presented in Fig. 2 are from
Cambrian sandstones sampled at the location marked with a star. Apatite fission track (AFT) ages (Corrigan et al. 1998) are marked with solid circles. $B$ Lake Buchanan, LBJ Lake LBJ. Modified from Morton and Long (1980), Corrigan et al. (1998), and Mosher (1998)

Table $1 \mathrm{~K}-\mathrm{Ca}$ analytical ages of Cambrian Lion Mountain glauconite

\begin{tabular}{|c|c|c|c|c|c|c|c|}
\hline Sample name* & ${ }^{40} \mathrm{Ca} /{ }^{42} \mathrm{Ca}$ norm ${ }^{* *}$ & $\mathrm{~K}(\mathrm{ppm})$ & $\mathrm{Ca}(\mathrm{ppm})$ & $\mathrm{K} / \mathrm{Ca}$ & ${ }^{40} \mathrm{~K} /{ }^{42} \mathrm{Ca}$ & $\varepsilon_{\mathrm{Ca}}$ & $\mathrm{Age}^{\dagger}$ \\
\hline GL 105 & 151.184 & 39815.90 & 1077.66 & 36.95 & 0.682 & 11.14 & $434 \pm 9$ \\
\hline GL 150 & 151.315 & 54122.28 & 442.46 & 122.32 & 2.259 & 19.8 & $246 \pm 11$ \\
\hline GL 247 & 151.288 & 36949.89 & 309.28 & 119.54 & 2.206 & 18.02 & $230 \pm 10$ \\
\hline GL 420 & 151.273 & 36949.89 & 316.64 & 116.69 & 2.151 & 17.04 & $223 \pm 6$ \\
\hline GL 105L & 151.223 & 34141.50 & 502.89 & 67.89 & 1.239 & 13.7 & $429 \pm 10$ \\
\hline GL 247L & 151.232 & 27581.43 & 360.38 & 76.53 & 1.393 & 14.29 & $285 \pm 7$ \\
\hline GL 420L & 151.125 & 15183.97 & 515.81 & 29.44 & 0.536 & 7.19 & $365 \pm 9$ \\
\hline
\end{tabular}

* The numbers in the sample names correspond to the size fractions described in the text. The "L" indicates that the sample was leached for 15 min with $1 \mathrm{M} \mathrm{HCl}$

** Normalized to the six standards bracketing the sample analysis, which in turn are normalized to a ${ }^{40} \mathrm{Ca} /{ }^{42} \mathrm{Ca}$ ratio of 151.016 (Marshall and DePaolo 1982)

${ }^{\dagger}$ Errors are a function of the $1 \sigma$ deviation of the mean standard isotopic ratios bracketing the sample analysis

from Corrigan et al. 1998 (Fig. 2b). We interpret this as indicating that the $\mathrm{K}-\mathrm{Ca}$ system in glauconite is sensitive to partial retention at temperatures greater than $50^{\circ} \mathrm{C}$, particularly if those elevated temperatures are sustained for periods of geologic time on the order of $10^{7}-10^{8}$ years. This suggests that $\mathrm{K}-\mathrm{Ca}$ is behaving as a low-temperature thermochronometer, and the glauconites studied here are being held in a partial $\mathrm{Ca}$ retention zone for much of the mid-late Paleozoic. The lack of $\mathrm{K}-\mathrm{Ca}$ ages younger than $223 \mathrm{Ma}$ indicates that an unroofing event had occurred by mid-Triassic time, and glauconites experienced no further reheating to greater than $50^{\circ} \mathrm{C}$. This is consistent with the timing of post-Ouachita orogenic cooling and exhumation described in Corrigan et al. 1998.

The $\mathrm{K}-\mathrm{Ca}$ isochron age of all glauconite fractions measured in this study is $375 \pm 50 \mathrm{Ma}$. This isochron can 
Fig. 2 a Comparison of the distribution of $\mathrm{K}-\mathrm{Ca}$ and $\mathrm{Rb}-\mathrm{Sr}$ glauconite ages from the Cambrian Lion Mountain sandstone and apatite fission track ages from the Precambrian Llano basement, with the exception of the youngest age (circled), which is from Pennsylvanian sandstone. K-Ca ages are from this study, $\mathrm{Rb}-\mathrm{Sr}$ ages are from Morton and Long (1980) and apatite fission track ages are from Corrigan et al. (1998). b Llano basement burial history based on apatite fission track length distributions and stratigraphic information. Replotted from Corrigan et al. (1998)

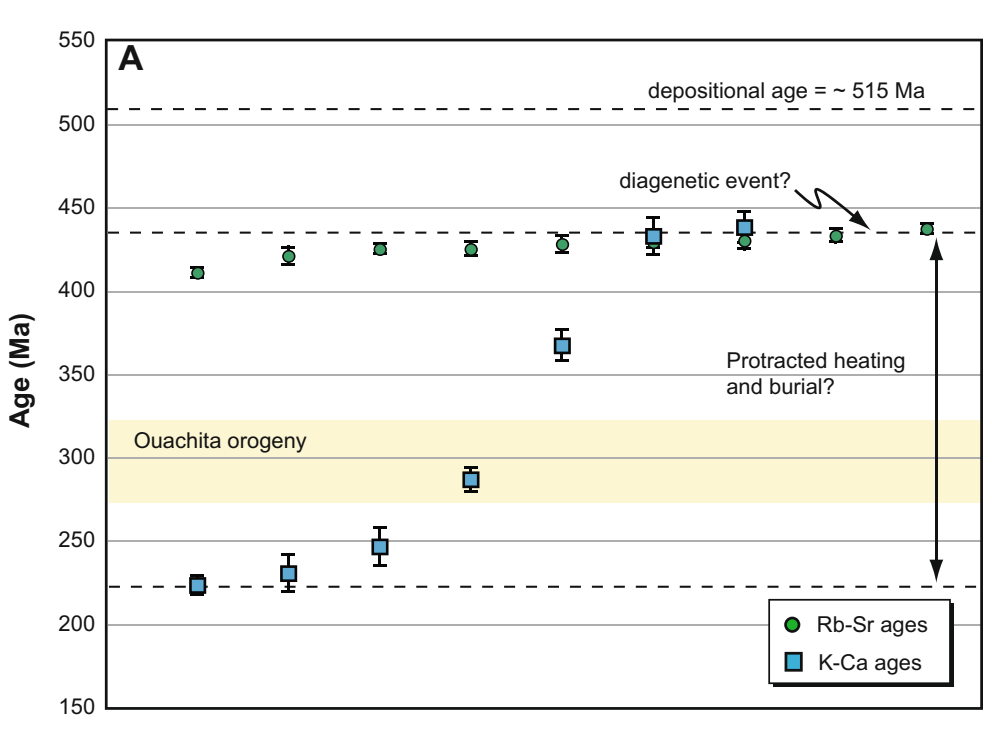

$\mathrm{T}\left({ }^{\circ} \mathrm{C}\right)$

20406080100120

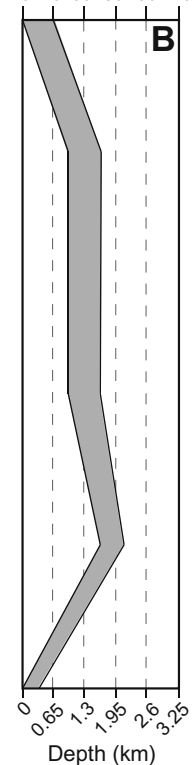

be reproduced by about $30 \%$ partial retention of Ca for first of $300 \mathrm{My}$ of glauconite residence in the upper crust and $223 \mathrm{My}$ of continuous decay and complete retention of $\mathrm{Ca}$ in the glauconite mineral structure (Fig. 3).

\section{Closure temperature of $\mathrm{Ca}$ in glauconite}

Preliminary estimates of the closure temperature of $\mathrm{Ca}$ in glauconite were made using the classic relationships described by Dodson (1973):

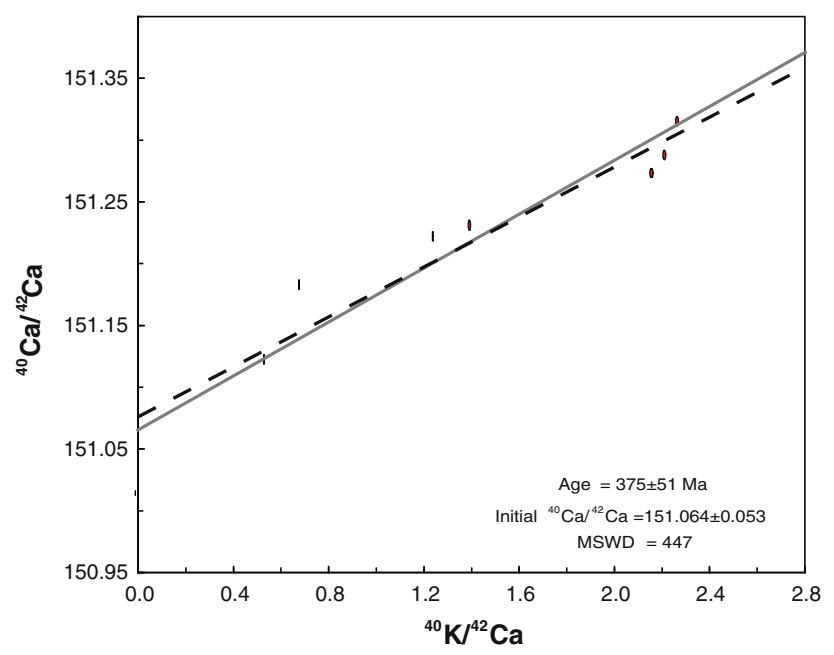

Fig. $3 \mathrm{~K}-\mathrm{Ca}$ average isochron age for all fractions of glauconite analyzed in this study. The dashed line represents a modeled isochron assuming $223 \mathrm{My}$ of decay and $100 \%$ retention of $\mathrm{Ca}$ and $300 \mathrm{My}$ of decay and $30 \%$ of Ca retention, as discussed in text
$E / R T_{c}=\ln \left(A \tau D_{o} / r^{2}\right)$

and

$\tau=R T_{c}^{2} / E(\mathrm{~d} T / \mathrm{d} t)$

where $E$ is activation energy, $R$ is the universal gas constant, $T_{c}$ is closure temperature, $A$ is a geometric constant ( $A=27$, using a cylindrical model), $D_{0}=$ frequency factor, $r$ is the effective diffusive radius, and $\mathrm{d} T / \mathrm{d} t$ is cooling rate. $T_{c}$ of $\mathrm{Ca}$ in glauconite can only be loosely estimated, as very little is known about the parameters governing glauconite. An activation energy $(E)$ of $4.182 \mathrm{~kJ} / \mathrm{mol}$ is chosen based upon the determined activation energy of $\mathrm{Sr}$ in biotite $(5.02 \mathrm{~kJ} / \mathrm{mol}-$ Dodson 1973), and the estimated ratio of $E_{S r} / E_{C a}$ in micas (Fletcher et al. 1997). Frequency factor $\left(D_{0}\right)$ is ill constrained as there is no diffusion information presently available for $\mathrm{Ca}$ in glauconite. We assign a $D_{0}$ value of 1 , intermediate between estimated $D_{0}$ for $\mathrm{Sr}$ in biotite (Fletcher et al. 1997) and $\mathrm{Ar}$ in muscovite (Harrison et al. 2009).

Unlike in most other systems where the mineral grain itself functions as the effective diffusive domain, the complexity of the glauconite structure makes it difficult to measure the diffusive radius. Glauconite forms by the uptake of $\mathrm{K}$ and $\mathrm{Fe}$ in degraded micaceous silicates. It does so most readily in micro-reducing environments created by the empty shells of marine microorganisms (Clauer et al. 1992; Stille and Clauer 1994). Morphologically, therefore, glauconite tends to occur as rounded, sand-sized grains, or pellets that are typically $0.1-0.5 \mathrm{~mm}$ in size. (For reference, the glauconite grains studied here were sieved into size fractions ranging from 63 to $420 \mu \mathrm{m}$ ). The individual glauconite crystallites that are forming inside of the pellets, 


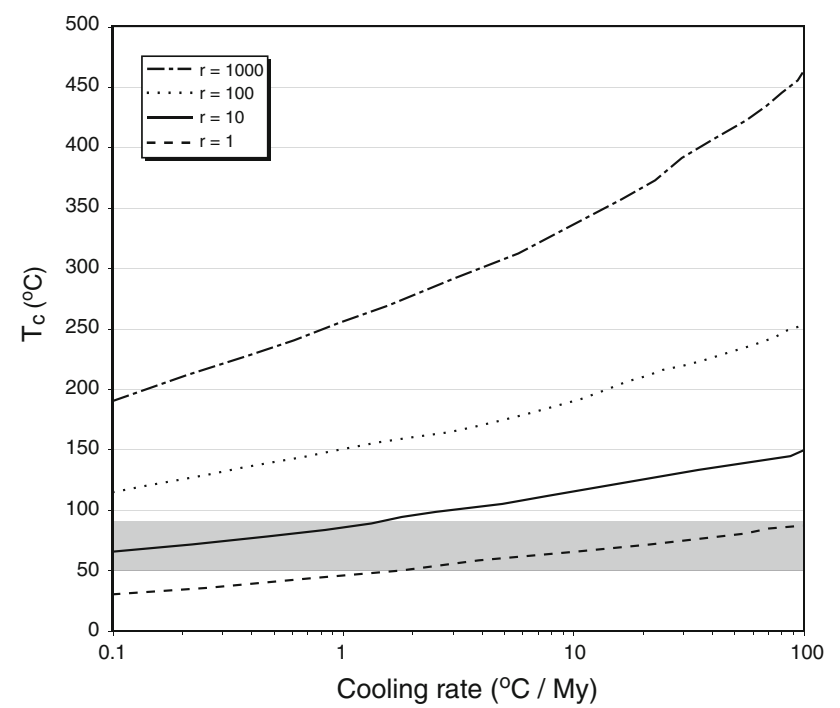

Fig. 4 Closure temperature of $\mathrm{Ca}$ in glauconite as a function of cooling rate. Curves were modeled using classic relationships described in Dodson, 1973. The gray rectangle represents the range of temperatures (inferred from apatite fission track data-Corrigan et al. 1998) thought to be partially resetting Cambrian glauconites

however, are much smaller and are capable of adsorbing and expelling ions during their slow maturation (Stille and Clauer 1994). There are numerous internal glauconite morphologies, but the most commonly described are randomly oriented mica flakes. Although the dimensions of the glauconite microcrystals are almost certainly variable, they could be micron to submicron in size. It is not known whether or not the exterior pellet acts as a diffusive boundary or if diffusion is occurring on a smaller scale within the pellet.

Closure temperatures for $\mathrm{Ca}$ in glauconite were modeled as a function of cooling rates using the parameters described earlier (Fig. 4). The different curves represent the relationship between $T_{c}$ and $\mathrm{d} T / \mathrm{d} t$ for four different effective diffusive radii, ranging from 1 to 1,000 microns. Typical pellet sizes are in the 100 to 1,000 micron range, whereas microcrystalline glauconitic clays within the pellets might be 1 to 10 microns in size (or conceivably smaller). Closure temperatures at a given cooling rate are higher for larger effective diffusive radii and lower for smaller diffusive domains. Estimates of closure temperature of $\mathrm{Ca}$ in glauconite are highly dependent upon the cooling rate and diffusive radius chosen. Apatite fission track data from the Llano basement are indicative of a slow, protracted cooling history (Corrigan et al. 1998). Erosion of the Llano region was likely slow for much of the Paleozoic, as basement rocks appear not have been exhumed to levels above the partial annealing zone for AFT. For that reason, we estimate cooling rates to be in the range of $0.5-1{ }^{\circ} \mathrm{C} / \mathrm{My}$. Given the sizes of the glauconite grains analyzed $(63-420 \mu \mathrm{m})$, and the probability that $\mathrm{Ca}$ loss is occurring at scales smaller than the pellet size, $10 \mu \mathrm{m}$ is chosen as the preferred $r$ value. For those cooling rate and diffusive radius parameters, the closure temperature of $\mathrm{Ca}$ in glauconite is around $85^{\circ} \mathrm{C}$. These temperatures are slightly higher than the temperatures estimated to partially reset the $\mathrm{K}-\mathrm{Ca}$ system in glauconite based on AFT data. Although they cannot be considered definitive values, because so little is known about $\mathrm{Ca}$ diffusion in glauconite, the broad range of closure temperatures presented here is generally very low and supports the concept of $\mathrm{K}-\mathrm{Ca}$ behaving as a low-temperature thermochronometer in basin systems.

\section{Discussion}

Assuming that the ages reported here are meaningful, there are three plausible interpretations of the younger than depositional ages measured in this study are as follows: (a) protracted authigenic growth of glauconite over large geologic periods, (b) late $\mathrm{K}$ addition, via diagenetic processes, and (c) diffusive Ca loss partially above a closure temperature.

It is widely accepted that glauconite grows at the sweater-sediment interface over extended periods of time (Smith et al. 1998). However, protracted authigenic growth of glauconite takes place over time periods of hundred of thousand of years to as much as $5 \mathrm{My}$ (Odin and Dodson 1982; Smith et al. 1998; Meunier and El Albani 2007), and not tens to hundreds of million years. We therefore rule out the hypothesis that the distribution of ages is related to extended authigenic growth.

Late addition of potassium during diagenesis is more difficult to quantify. Qualitative indicators such as freshness of hand samples argue against significant chemical disturbance during diagenesis in the studied rocks. In addition, the concentration of $\mathrm{K}(\%)$ in our glauconites is well within the range (1-8\%) of authigenic glauconites (Thompson and Hower 1973), suggesting it is unlikely that these samples have been subjected by significant uptake of potassium after deposition. We therefore suggest that the studied glauconites have not been subjected to intake of potassium subsequent to their initial growth during the Cambrian.

The third hypothesis, diffusive Ca loss is the most likely explanation for the distribution of ages, and is consistent with independent geologic and thermochronologic constraints from the region. The average isochron age for the studied samples is $375 \mathrm{Ma}$, which requires that about $30 \%$ of the radiogenically produced $\mathrm{Ca}$ was retained in the glauconite structure prior to unroofing of these rocks at the end of Permian (Fig. 4). 


\section{Conclusions}

$\mathrm{K}-\mathrm{Ca}$ ages from Cambrian glauconites are highly variable and demonstrate that the $\mathrm{K}-\mathrm{Ca}$ system cannot be used to reliably reproduce depositional ages of this sedimentary package. In the examples presented here, $\mathrm{K}-\mathrm{Ca}$ ages are younger than presumed depositional ages by $16-56 \%$. The distribution of $\mathrm{K}-\mathrm{Ca}$ ages in glauconite, however, can yield useful information about the thermal and hydrologic histories of basins. Data from the Llano uplift suggest that the mobility of $\mathrm{Ca}$ in glauconite is sensitive to burial to shallow crustal depths and thermal fluctuation, such that $\mathrm{Ca}$ ions exchange out of the mineral structure at temperatures above $\sim 50^{\circ} \mathrm{C}$. This is slightly lower than closure temperature estimates of $\mathrm{Ca}$ in glauconite, which range from $\sim 60$ to $100^{\circ} \mathrm{C}$ for slow cooling rates of $1^{\circ} \mathrm{C} / \mathrm{My}$. More rigorous work investigating the diffusive behavior of $\mathrm{Ca}$ in micas needs to be done, but on the basis of preliminary results presented here, $\mathrm{K}-\mathrm{Ca}$ in glauconite has the potential to be used as a low-temperature basin thermochronometer.

Acknowledgments The authors thank Dr. Wolf-Christian Dullo, the science editor of the Journal, Dr. David Schuster and an anonymous reviewer for their constructive criticism provided on an earlier version of this manuscript. We also thank Leon Long for his help in the field and insightful discussion of the Llano uplift and Paleozoic glauconites. Mark Baker provided additional technical and mass spectrometric support. This work was supported by PRF Grant \#46126-AC8 to Ducea and AAPG and GSA student grants to Cecil.

Open Access This article is distributed under the terms of the Creative Commons Attribution Noncommercial License which permits any noncommercial use, distribution, and reproduction in any medium, provided the original author(s) and source are credited.

\section{References}

Ahrens LH (1951) The feasibility of a calcium method for the determination of a geological age. Geochim Cosmochim Acta $1: 312-316$

Baadsgaard H (1987) Rb-Sr and K-Ca isotope systematics in minerals from potassium horizons in the Prairie evaporite Formation, Saskatchewan, Canada. Chem Geol 66:1-15

Becker ML, Rasbury ET, Meyers WJ, Hanson GN (2002) U-Pb calcite age of the Late Permian Castile Formation, Delaware Basin: a constraint on the age of the Permian-Triassic boundary (?). Earth Planet Sci Lett 203:681-689

Brookins DG, Register JK, Krueger HW (1980) Potassium-argon dating of polyhalite in southeastern New Mexico. Geochim Cosmochim Acta 44:635-637

Cecil MR (2009) Development and application of geochronometric techniques to the study of Sierra Nevada uplift and the dating of authigenic sediments. PhD dissertation, University of Arizona, $176 \mathrm{pp}$

Clauer N, Keppens E, Stille P (1992) Sr isotopic constraints on the process of glauconitization. Geology 20:133-136

Clauer N, Srodon J, Francu J, Sucha V (1997) K-Ar dating of illite fundamental particles separated from illite-smectite. Clay Miner $32: 181-196$
Clauer N, Huggett JM, Hillier S (2005) How reliable is the K-Ar glauconite chronometer? A case study of Eocene sediments from the Isle of Wight. Clay Miner 40:167-176

Corrigan J, Cervany PF, Donelick R, Bergman SC (1998) Postorogenic denudation along the late Paleozoic Ouachita trend, south central United States of America: magnitude and timing constraints from apatite fission track data. Tectonics 17:587-603

Dodson MH (1973) Closure temperature in cooling geochronological and petrological systems. Contrib Mineral Petrol 40:259-274

Evans JA, Zalasiewicz JA, Fletcher I, Rasmussen B, Pearce NJG (2002) Dating diagenetic monazite in mudrocks: constraining the oil window? J Geol Soc 159:619-622

Evernden JF, Curtis GH, Obradovich J, Kistler R (1961) On the evaluation of glauconite and illite for dating sedimentary rocks by the Potassium-Argon method. Geochim Cosmochim Acta 23:78-99

Fletcher IR, McNaughton NJ, Pidgeon RT, Rosman KJR (1997) Sequential closure of $\mathrm{K}-\mathrm{Ca}$ and $\mathrm{Rb}-\mathrm{Sr}$ isotopic systems in Archaean micas. Chem Geol 138:289-301

Gopalan K (2008) Conjunctive K-Ca and Rb-Sr dating of glauconies. Chem Geol 247:119-123

Harrison TM, Celerier J, Aikman AB, Hermann J, Heizler MT (2009) Diffusion of Ar-40 in muscovite. Geochim Cosmochim Acta 73:1039-1051

Herzog LF (1956) Rb-Sr and K-Ca analyses and ages, Nuclear Processes in Geologic Settings, National Research Council, Commision of Nuclear Science, Nuclear Science Series Report 19, pp 114-130

Hurley PM (1961) Glauconite as a possible means of measuring age of sediments. Ann NY Acad Sci 91:294-296

Hurley PM, Cormier RF, Fairbain HW, Hower J, Pinson WH (1960) Reliability of glauconite for age measurements by $\mathrm{K}-\mathrm{Ar}$ and $\mathrm{Rb}-$ Sr methods. Am Assoc Pet Geol Bull 44:1793-1808

Marshall BD, DePaolo DJ (1982) Precise age determinations and petrogenetic studies using the K-Ca method. Geochim Cosmochim Acta 53:917-922

Marshall BD, Woodard HH, DePaolo DJ (1986) K-Ca-Ar systematics of authigenic sanidine from Waukau, Wisconsin, and the diffusivity of argon. Geology 14:936-938

McBride EF (1988) Contrasting diagenetic histories of concretions and host rock, Lion Mountain sandstone (Cambrian), Texas. Geol Soc Am Bull 100:1803-1810

McNaughton NJ, Rasmussen B, Fletcher IR (1999) SHRIMP uranium-lead dating of diagenetic xenotime in siliciclastic sedimentary rocks. Science 285:78-80

Meunier A, El Albani A (2007) The glauconite-Fe-Illite-Fe-smectite problem: a critical review. Terra Nova 19:95-104

Montag RL, Seidemann DE (1981) A test of the reliability of Rb-Sr dates for selected glauconite morphologies of the Upper Cretaceous (Navesink Formation) of New Jersey. Earth Planet Sci Lett 52:285-290

Morton JP, Long LE (1980) Rb-Sr dating of Paleozoic glauconite from the Llano region, central Texas. Geochim Cosmochim Acta 44:663-672

Mosher S (1998) Tectonic evolution of the southern Laurentian Grenville orogenic belt. Geol Soc Am Bull 110:1357-1375

Nagler TF, Villa IM (2000) In pursuit of the K-40 branching ratios: K-Ca and Ar-39-Ar-40 dating of gem silicates. Chem Geol 169:5-16

Obradovich J (1988) A different perspective on glauconite as a chronometer for geologic time scale studies. Paleoceanography 3:757-770

Odin GS (ed) (1982) Numerical dating in stratigraphy. John Wiley \& Sons, New York, p 1040

Odin GS, Dodson MH (1982) Zero isotopic ages of glauconites. In: Odinl GS et al (eds) Numerical dating in stratigraphy, vol 14. Wiley Inter-science, New York, pp 277-305 
Owens JP, Sohl NF (1973) Glauconites from New Jersey-Maryland coastal plain: their K-Ar ages and application in stratigraphic studies. Geol Soc Am Bull 84:2811-2838

Polevaya NI, Titov NE, Belyaer VS, Sprintsson VD (1958) Application of the calcium method in the absolute age determination of sylvites. Geochemistry 8:897-906

Renne PR, Sharp WD, Montanez IP, Becker TA, Zierenberg RA (2001) Ar-40/Ar-39 dating of Late Permian evaporites, southeastern New Mexico, USA. Earth Planet Sci Lett 193:539-547

Rongbing Y (1989) Application of glauconite in sedimentary geochronology. Chin J Geochem 8:283-291

Shih CY, Nyquist LE, Bogard DD, Wiesmann H (1994) K-Ca AND $\mathrm{Rb}$-Sr dating of 2 lunar granites-relative chronometer resetting. Geochim Cosmochim Acta 58:3101-3116
Smith PE, Evensen NM, York D, Odin GS (1998) Single-grain Ar-40Ar-39 ages of glauconies: implications for the geologic time scale and global sea level variations. Science 279:1517-1519

Srodon J, Clauer N, Eberl DDD (2002) Interpretation of K-Ar dates of illitic clays from sedimentary rocks aided by modeling. Am Mineral 87:1528-1535

Stille P, Clauer N (1994) The process of glauconitization-chemical and isotopic evidence. Contrib Mineral Petrol 117:253-262

Thompson GR, Hower J (1973) Explanation for low radiometric ages from glauconite. Geochim Cosmochim Acta 37:1473-1491 